\title{
POTRAYAL OF THE NINETEENTH CENTURY ENGLISH WOMEN IN JANE AUSTEN'S SENSE AND SENSIBILITY
}

\author{
${ }^{1)}$ Alamsyah, ${ }^{2)}$ Azmir Pasaribu, ${ }^{3)}$ Zulfan Sahri \\ Faculty of Literature \\ Islamic University of North Sumatra, Medan \\ Email: ${ }^{2)}$ azmir@sastra-uisu.ac.id, ${ }^{3)}$ syahrizulfan@yahoo.com
}

\begin{abstract}
The study has three points of discussion. The first deals with the rights of woman in obtaining property especially the one inherited from parents. The second does with the roles of women in the family. Once women married, their property rights are governed by English common law, legally absorbed by their husbands. Furthermore, married women could not make wills or dispose of any property without their husbands' consent. The third deals with the roles of women in society. A woman is surely forbidden to do any type of job or business. All is done by man. The main theory concerning property rights of women is proposed by Shanley (2000) who states that from the legal 'unity' of the husband and wife, it follows that a married woman could not sue or be sued unless her husband is also a party to the suit, could not sign contracts unless her husband joins her. And for the research method, the Descriptive Qualitative Approach proposed by Bogdan and Biklen (1992) is applied, concerning the opinions, experiences and feeling of individuals producing subjective data. It elaborates social phenomena as they occur naturally. The finding shows that all the female characters in the novel get into the problems of property rights, standings in family as well as in the society.
\end{abstract}

Keywoords: property, society, right, legal 'unity' 
Potrayal of the Nineteenth Century English Women in Jane Auste's Sense and Sensibility, Alamsyah, Azmir Pasaribu, Zulfan Sahri

\section{INTRODUCTION}

Sense and Sensibility is the story of two sisters, Elinor and Marianne Dashwood who with their mother and younger sister, Margaret, are forced into poverty through the untimely death of their father. Mr. Dashwood was previously married and all of the Dashwood fortune and the estate of Norland, is then bequeathed to John, his son by his first marriage, leaving the Dashwood women practically penniless. Elinor and Marianne are polar opposites where love is concerned. Marianne is the incurable romantic and Elinor is the practical, downto-earth person.

Elinor falls in love with Edward Ferrars and Marianne, for Willoughby. They spend happy moments in the company of these men and hope to be married to them. However, Edward turns out to be engaged to anopther girl, Lucy Steele and Willoughby plans to marry Miss Grey,a rich debutante. Next, Elinor learns of the marriage of Lucy Steele to Mr. Ferrars. Marianne goes through a period of depression and falls seriously ill. Elinor feels miserable to think of her Edward united with a lesser woman.

Marianne renews her enthusiasm for life and starts realizing the worth of Colonel Brandon. Elinor is relieved when Edward reveals the truth to her and then proposes. Marianne marries Colonel Brandon and Elinor marries Edward Ferrars.

There are three points of discussion in this study: Rights of Women during the nineteenth century of England; Family Life of women during this era 
and Social Life of Women. The last two talk of the roles and duties of women. Equality of rights are seldom discussed during this period or in other words it is always said that this is an era of women decayed rules of the state and tradition and concept of society.

The main theory concerning the property rights of women is proposed by Shanley (2000) stating that the legal status of married women prevents them from unilaterally participating in the civil legal system while for the research method, Descriptive Qualitative Approach is applied, the one proposed by Bogdan \& Biklen (1992: 87).

Each generation has its minority that is vocally fighting for change. For example, today it seems that everywhere you turn there is another news story about the struggle for gay and lesbian rights, whether it's about tax equality, military service, or the right to marry. 150 years ago, it was an even larger portion of the population's turn: women. Throughout the 19th century and into the 20th, women fought for equal rights under the law and most importantly the right to vote.

While it is true female monarchs had existed in previous centuries, these were largely due to accidents of birth and the death of male heirs. Though exceptions to the rule did exist, women in general were entirely shut out of the public sphere of 19th-century society unless they were accompanying their husbands or fathers. 
Potrayal of the Nineteenth Century English Women in Jane Auste's Sense and Sensibility, Alamsyah, Azmir Pasaribu, Zulfan Sahri

Across the Atlantic Ocean, similar women's rights movements were springing up decrying the existing social order in England and Europe. In England, for instance, groups of leading women's rights advocates, such as the Langham Place Group, met regularly to discuss women's issues and strategies for drumming up support for women's rights. In Great Britain, women were even more disadvantaged; there was absolutely no access to education beyond basic grade school, and women were not even allowed to inherit property or money from their dead husbands.

These groups of women organized protests, rallies, and other meetings both in Great Britain and in the United States, aiming to bring the cause of women's rights into the public consciousness. These women were joined in their calls for reform by liberal-minded men and philosophers, such as John Stuart Mill. This vocal agitation for change led to a wholesale reexamination of the relationships between men and women and the role of women in society. (Sarah, 2000: 112-130)

The property rights of women during most of the nineteenth century were dependent upon their marital status. Once women married, their property rights were governed by English common law, which required that the property women took into a marriage, or acquired subsequently, be legally absorbed by their husbands. Furthermore, married women could not make wills or dispose of any property without their husbands' consent. Marital separation, whether initiated by the husband or wife, usually left the women economically destitute, 
as the law offered them no rights to marital property. Once married, the only legal avenue through which women could reclaim property was widowhood. Women who never married maintain control over all their properties, including their inheritance. These women could own freehold land and had complete control of property disposal. The notoriety of the 1836 Caroline Norton Case highlighted the injustice of women's property rights and influenced parliamentary debates to reform property laws. The women's movement generated the support which eventually resulted in the passage of the Married Women's Property Law in 1882. England's mid-nineteenth century focus on married women's property rights culminated in the transformation of the subordinate legal status of married women.

Unmarried women, legally identified as female sole, had complete legal control of their own property. They had the right to dispose of their property and only used the assistance of a legal guardian if they chose. The distribution of property in unmarried women's wills differ from men's in that that these women gave preferences to their female relatives in dividing their property (Erickson, 1999: 67). This allowed female members of the family to live more comfortably, as women were more susceptible to a life of poverty. Unmarried women maintained control of their property as long as they remained unmarried.

The legal status of married women prevented them from unilaterally participating in the civil legal system. Shanley (2000: 121) explains that "From the legal 'unity' of the husband and wife it followed that a married woman could 
Potrayal of the Nineteenth Century English Women in Jane Auste's Sense and Sensibility, Alamsyah, Azmir Pasaribu, Zulfan Sahri

not sue or be sued unless her husband was also a party to the suit, could not sign contracts unless her husband joined her". The law of covertures also governed women's premarital legal contracts. Laurence notes, "English common law did not recognize pre-nuptial contracts; all contracts made by a woman were annulled by her marriage". Furthermore, married women lost the right to execute their own wills since legally all their property belonged to their husbands. With their husbands' consent, women executed wills to dispose of their personal property.

The laws that allowed married women to recapture property rights through widowhood were revised in the early nineteenth century. Once widowed, women were entitled to a dower, which was usually equivalent to one third of the husband's estate. The dower is the portion of the deceased husband's estate that his widow inherited for life. This inheritance did not represent a return of property that had been brought by women into the marriages. Women's dower rights during the eighteenth century were restricted by common law.

Dower only attaches to what is considered real property. Dower rights regarding real property changed to reflect economic changes in England. New commodities like stock and bank annuities replace land as major ingredients of wealth, and the law of dower changes to reflect this, limiting widows' rights to land but giving them equivalents in newer forms of wealth. The Dower Act of 1833 ultimately proved to favor men's property rights. "Its enactment allowed legal intellectuals to feel that they had corrected an error but preserved for 
individual women no socially enforced rights; an individual woman got nothing except what her own husband privately elected to bestow" (49). This change was viewed as an erosion of women's property rights as widows were only entitled to an equitable jointure of their husband's estate. Jointure assignments were an arrangement by which a husband settles property on his wife for her use after his death. The assignment of jointures deprived widows of legal rights over their husband's estates and allowed the valuable real property, which was land, to be left to male heirs. Estates in jointure were no longer required to be an estate in freehold land. Furthermore, men found other ways to defraud women of dower rights. Men in contemplation of marriage could and often did convey their property to trustees in order to, as they said, "avoid the inconvenience of dower attaching and for other purposes". Widows usually received substantially less valuable property than male heirs. However, unlike married women, they exercised control over the property and its disposal through wills. (Shanley, 2000: 187)

The Victorian era seems like another world to us. Yet the late Victorians were very familiar with many of the things we use every day. The one thing that was different was the place of women in society. There were of course perceptive women of independent original thought, but for the huge majority life was easier if they accepted that a woman's place was in the home. To lump all women of the Victorian era as one body would be wrong. The era spanned 64 years and changes in attitudes were gradually shifting as the century closed. 
Potrayal of the Nineteenth Century English Women in Jane Auste's Sense and Sensibility, Alamsyah, Azmir Pasaribu, Zulfan Sahri

Above in the heading we see a picture of the young Queen Victoria at 18. If you look at her in the top page of the Victorian Era you will see how she changed with the years.

Whether or not you agree with the facts today, the attitude of men toward women in the Victorian age was highlighted by some writers who wrote of women staying by the hearth with their needles whilst men wielded their swords.

The accepted reasoning was that the career for women was marriage. To get ready for courtship and marriage a girl was groomed like a racehorse. In addition to being able to sing, play an instrument and speak a little French or Italian, the qualities a young Victorian gentlewoman needed, were to be innocent, virtuous, biddable, dutiful and be ignorant of intellectual opinion. Right - Taking tea wearing lavish Victorian gowns in 1854. Fashion history images we see today are usually of beautifully gowned women, yet many working women as opposed to ladies such as these wore rags. (Perkin, 2010: 103)

Whether married or single, all Victorian women were expected to be weak and helpless, a fragile delicate flower incapable of making decisions beyond selecting the menu and ensuring her many children were taught moral values. A gentlewoman ensured that the home was a place of comfort for her husband and family from the stresses of Industrial Britain.

It was a hypocritical period when relationships were quite artificial. Until late in the century in 1887 a married woman could own no property. Then in 1887 the Married Woman's Property Act gave women rights to own her own property. Previously her property, frequently inherited from her family, 
belonged to her husband on marriage. She became the chattel of the man. During this era if a wife separated from her husband she had no rights of access to see her children. A divorced woman had no chance of acceptance in society again.

It takes a considerable leap of the imagination for a woman of the $21 \mathrm{st}$ century to realize what her life would have been like had she been born 150 years ago. We take for granted nowadays that almost any woman can have a career if she applies herself. We take for granted that women can choose whether or not to marry, and whether or not to have children, and how many.

Women of the 19th century had no such choices. Most lived in a state little better than slavery. They had to obey men, because in most cases men held all the resources and women had no independent means of subsistence. A wealthy widow or spinster was a lucky exception. A woman who remained single would attract social disapproval and pity. She could not have children or cohabit with a man: the social penalties were simply too high.

Women's purpose was to serve men and (men's) offspring, by marrying and reproducing, by raising children, looking after the sick, nursing and by teaching at elementary level. Men did everything they could to keep women constricted within these spheres. Girls received less education than boys, were barred from universities, and could obtain only low-paid jobs. All professions that needed academic qualifications were closed to women. 
Potrayal of the Nineteenth Century English Women in Jane Auste's Sense and Sensibility, Alamsyah, Azmir Pasaribu, Zulfan Sahri

Most women had little choice but to marry and upon doing so everything they owned, inherited and earned automatically belonged by law to their husband. This meant that if an offence or felony was committed against her, only her husband could prosecute. Furthermore, rights to the woman personally - that is, access to her body - were his. Not only was this assured by law, but the woman herself agreed to it verbally: written into the marriage ceremony was a vow to obey her husband, which every woman had to swear before God as well as earthly witnesses. Not until the late 20th century did women obtain the right to omit that promise from their wedding vows. (Fausto-Sterling, 2010: 86)

At the same time, a young girl was not expected to focus too obviously on finding a husband. Being 'forward' in the company of men suggested a worrying sexual appetite. Women were assumed to desire marriage because it allowed them to become mothers rather than to pursue sexual or emotional satisfaction.

Girls usually married in their early to mid-20s. Typically, the groom would be five years older. Not only did this reinforce the 'natural' hierarchy between the sexes, but it also made sound financial sense. A young man needed to be able to show that he earned enough money to support a wife and any future children before the girl's father would give his permission. Some unfortunate couples were obliged to endure an engagement lasting decades before they could afford to marry. 
Every man had the right to force his wife into sex and childbirth. He could take her children without reason and send them to be raised elsewhere. He could spend his wife's inheritance on a mistress or on prostitutes. Sometimes, somewhere, all these things - and a great many more - happened.

If a woman was unhappy with her situation there was, almost without exception, nothing she could do about it. Except in extremely rare cases, a woman could not obtain a divorce and, until 1891, if she ran away from an intolerable marriage the police could capture and return her, and her husband could imprison her. All this was sanctioned by church, law, custom, history, and approved of by society in general. Nor was it the result of ancient, outdated laws: the new (1857) divorce act restated the moral inequality. Mere adultery was not grounds for a woman to divorce a man; however, it was sufficient grounds for a man to divorce his wife.

In the 19th century Britain women were expected to marry and have children. However, there was in fact a shortage of available men. Census figures for the period reveal there were far more women than men. There were three main reasons why women outnumbered men. The mortality rate for boys was far higher than for girls; a large number of males served in the armed forces abroad and men were more likely to emigrate than women. By 1861 there were 10,380,285 women living in England and Wales but only 9,825,246 men. (Fausto-Sterling, 2010: 196) 
Potrayal of the Nineteenth Century English Women in Jane Auste's Sense and Sensibility, Alamsyah, Azmir Pasaribu, Zulfan Sahri

\section{DISCUSSION}

During the Victorian period men and women's roles became more sharply defined than at any time in history. In earlier centuries it had been usual for women to work alongside husbands and brothers in the family business. Living 'over the shop' made it easy for women to help out by serving customers or keeping accounts while also attending to their domestic duties. As the 19th century progressed men increasingly commuted to their place of work, the factory, shop or office. Wives, daughters and sisters were left at home all day to oversee the domestic duties that were increasingly carried out by servants. From the 1830s, women started to adopt the crinoline, a huge bell-shaped skirt that made it virtually impossible to clean a grate or sweep the stairs without tumbling over.

English women of the nineteenth century have little choice to do what they want in their life. They should obey men because in most cases, men hold all the resources and women have no independent means of subsistence. Besides, women receive less education then en and could obtain only low-paid jobs.

A woman's sole purpose is to marry and reproduce. Most women have little choice but to marry and upon doing so everything they own, inherited and earned automatically belonged to their husband. This means that if an offence or felony is committed against her, only her husband could prosecute. Furthermore, rights to the woman personally, that is, access to her body is his. Not only is this assured by the law, but the woman herself agrees to it verbally and written into 
the marriage ceremony is a vow to obey her husband, which every woman has to swear before God as well earthy by witnesses.

\section{Women's Property Rights}

The main issue here is the rights of women over the family properties after marriage. The property rights of women during most of the nineteenth century in England are dependent upon their marital status. Once women are married, their property rights are governed by English common law, which requires that all the properties of the women are legally absorbed into their husbands' rights. Married women could not make wills or dispose of any property without their husbands' consent. Marital separation, whether initiated by the husband or the wife, usually leave the woman economically destitute as the law offers them no rights to marital property. Once married, the only legal avenue through which women could reclaim property is widowhood. Women who never get married maintain their control over all their property, including their inheritance. These women could own freehold land and have complete control of property disposal.

The property owned by women in Victorian English is usually inherited from fathers. To protect the status of their daughters, most fathers include them in the distribution of the patrimony. However, the type of property inherited by sons and daughters also differ.

The illustrations above are also shown in the novel Sense and Sensibility. Jane Austen (1990) verifies that after the death of Henry Pashwood, his son Mr. 
Potrayal of the Nineteenth Century English Women in Jane Auste's Sense and Sensibility, Alamsyah, Azmir Pasaribu, Zulfan Sahri

John Dashwood takes over the whole property inherited from his father, although his father has already told him before his death that John could share the property with his sisters.

When he gave a promise to his father, he meditated within himself to increase the fortunes of her sisters by the presence of a thousand pounds apiece. He then really thought them equal to it. The prospect of four thousand a year, in addition to his present income, besides the remaining half of his own mother's fortunes. (Austen, 1990: 4)

This shows that John Dashwood is not consistent to his own words when he promises that he would share the property with his sisters before the death of his father. This happens because he is supported by the government law stating that he, as the son, could take control over the whole property. Fathers normally give their daughters shares comparable in value with those of their brothers, although girls usually inherited personal property while boys more often inherit real property and John has already manipulated this concept by taking all for him.

In English common law wives could hold no freehold land or real property except through their husbands; nor could they alter or dispose the property without the consent of their husbands though the property belongs to them.

If a woman is not happy with her marriage life and then asks for a divorce, she will get nothing. And if the woman simply runs away from her husband she could be give a penalty by the court and usually she has to go to the 
prison. Again this could happen owing to the approval of the law, church, customs, and also society. Then no woman has a right to divorce a man. So in short a woman has no right at all regarding any type of property.

You may directly go to the court or any others ... I take all for the sake of you as you cannot manage the property. It is usually lost in your hands. I am not going to get involved in that loss. You never know the means of money; how could you come through it? And then who will take a trust of you in the property case. (Austen, 1990: 34)

This shows that women are also underestimated in controlling matters of property. John in his grounds tells his sisters that he is not sure of their capability in controlling their property. He is the one that is given rights either by the father or by the law to control over the whole property of their father. Then John is not afraid if what he has done will brought to the court. What he is thinking now is to give the sisters as little as possible from the whole inheritance. John together with the community in which he lives always thinks that women are weak and cannot be reliable.

\section{Women's Family Life}

Conventionally, a family is an institution having a system of rules generally shared, and of roles locally exhibited in homes throughout the country. This shows that the laws or regulations in the family life have stood for the equality of rights. Every family member, man or man has rights to do many things as long as they do not break the laws illegally. However, in the nineteenth 
Potrayal of the Nineteenth Century English Women in Jane Auste's Sense and Sensibility, Alamsyah, Azmir Pasaribu, Zulfan Sahri

century of England, the sharing of rights hardly happens. The man often becomes the winner and the woman is in the losing side.

Owing to the different treatments that have impeded the women for a long a time, most women feel that they need to help one another in any situation although often they misuse the right that have been given to them. This can be seen from the role of Mrs. Fanny Ferrars, John Dashwood's wife, who defends her sisters-in-law, Elinor, Marriane and Margaret, in getting their inheritance.

You cannot go such a thing to them, to your sisters. They have rights too to get what they deserve. You are so cruel and sorry to say a little bit thinking of yourself. They are coming from your mother too. You have to think them. And as a brother you should show your responsibility instead of repression you gave them. No talk of laws ... This matters a lot for their future. When they collapse, still they are yours, your sisters. Again, please, I plead you to rethink what you want to do, taking all giving only some remains. (Austen, 1990: 54)

Mrs. Ferrars tries her best to help her sisters-in-law to get what they deserve to get, although behind this all, she also wants to get a support from her sisters-in-law to help her own sisters in the same matters. Fanny Ferrars tells her husband, John Dashwood that she does not approve of what he has done to his sisters by sharing them only three thousand pounds as their inheritance as she thinks that this is too little. They need more for the safety of their future.

Fanny Ferrars makes a further approach to her husband so softly in order that he will be ready to think again about the inheritance to be given to his sisters. 
She says that the decision is not fair although he and his sisters have different mothers, but they are still his sisters. She tries to make her husband realize that they are brother and sisters that come from the same blood. They should not be differentiated from one another.

In this respect, Fanny Ferrars wants to show to her husband that she is a good wife, who really cares about her husband's problems. And she is sure that her attempts will enable her husband to willingly make any changes to the recommended-shared inheritance in the family.

During these times, most wives are expected to have a decent profession. This is so the husband will not be embarrassed of telling other people what she does. A good wife plans and organizes her schedule carefully. Even after her own tiring day at work, she makes sure she comes home before her husband so she can have the dinner prepared. She plans ahead, even the night before, to have a delicious meal on time. This is a way of letting her husband know that she has been thinking about and is concerned about his needs. Most men are hungry when they come home and the prospect of a good meal is part of the warm welcome needed.

Furthermore, Ferrars's persuasion has actually influenced Mr. John Dashwood's mind in feeling. Since then, he begins to think that his wife's words more or less are quite logical. Nevertheless, it is very hard for him to do it because he feels that he is the only man in the family who has total rights to the property that his father has left for them. He also thinks that his three sisters will 
Potrayal of the Nineteenth Century English Women in Jane Auste's Sense and Sensibility, Alamsyah, Azmir Pasaribu, Zulfan Sahri

later get married; therefore they do not deserve to get more from the division of the property inheritance.

Well, well, now they are not married yet, and the property probably could be shared. What about when they are married, then all the property will go to their husband. This is a waste, for sure. Outsiders will enjoy ours, and again this is also unfair. (Austen, 1990: 62)

John Dashwood persistently states that his sisters could not get all the shared property. He is just ready to give some to them as he thinks that the property that is given today will go to another person. And he thinks that this is also unfair. At the same time, he never forgets what his wife has told him about the sharing of the property equally. He begins to think to share ten thousand pounds for his sister; this means that he is ready to give some more to his sisters.

To be sure it is: and, indeed, it strikes me that they can want no addition at all. They will have ten thousand pounds divided amongst them. If they marry, they will be sure of doing well, and if they do not, they may all live comfortably together on the interest of ten thousand pounds. (Austen, 1990: 68)

Mr. John Dashwood's willingness shows that he is not a greedy man. He is actually a reliable person that his father always trusts him.

Greed is also a bad thing because it can result in people doing things that they would not normally do. If we have a good job and are making a lot of money, we are more capable of getting things we want, as opposed to someone on a low income. And this makes John apart from greed. 
He becomes so rigid and looks strict because he is afraid that he will break the laws. In fact, he likes to help, if it is possible, and even it is important for the sake for his sisters' welfare. However, he still inquires about his wife's interference to the case. He then begins to think whether his wife intends to get any advantage from his willingness to share the property. This is because he feels something strange with his wife's extravagant wish and intention to that matter. Although he has decided to add the money for his sisters, he wants to know the reasons why his wife does so.

"Oh, beyond anything great! What brother on earth would do half so much for his sisters, even if really sisters! And as it is only half blood. But you have such a generous spirit." (Austen, 1990: 70)

John Dashwood thinks that logically there will be no man who is going to share anything equally to his sisters, especially when the sisters are not his own. The sisters are only half-blood. He actually shows his anger to his wife for her interference in this matter. He is afraid that his wife has got some hidden intentions. Then he begins to think not to give anything to his wife, though he does not express his intentions before his wife.

Jane Austen's description to the above matter is to show that a woman has to rethink the fundamental sources of her identity in a family life. This means that a wife should not make any interference with her husband's business and problem and even then takes chances to get advantages from her husband's property. As a good wife, she has to think twice about what she should do and 
Potrayal of the Nineteenth Century English Women in Jane Auste's Sense and Sensibility, Alamsyah, Azmir Pasaribu, Zulfan Sahri

make in order that it will not give a trouble to her position and role as a household wife in a family.

In the nineteenth century of England, it is not easy to be a wife in a family. She must know how to manage the family especially about financial matters while at the same time she is completely under control of her husband. Married men and women are not financially equal. Although married women have had the legal right to control and manage their own financial affairs since the early years of this century, in practice, this has seldom been accompanied by real financial independence. This higher average wage earned by men, and the more restricted employment opportunities available to men, together with their heavier domestic responsibilities, means that most married women are dependent on their husbands' earning power for a large part of their lives.

In this novel it is pictured that the women are all conscious of the fact that they must have got additional, important responsibilities in their lives. They should consider these when planning how to use their time, both at home and at work. However, in the nineteenth century, especially for the married women, they should surely realize that they have no opportunity to make any work plan or business outside, because they only have rights for their children and childcare managements. Besides, they are not equal in financial affairs; husbands have total power upon this matter.

Regarding this, Mrs. Dashwood pays a great attention to her daughter's love affair. She knows about the circumstances, which is growing between her 
daughter, Elinor and Marriane and the men whom they love. Elinor falls in love with Edward, and Marriane with Willoughby. When she knows that both her daughters intend to get married to them, she is quite happy because she always hopes that her daughters will marry a wealthy man like Edward.

Edward had been staying several weeks in the house before he engaged much of Mrs. Dashwood's attention; for she was, at that time, in such affliction as rendered her careless of surrounding objects. She saw only that he was quiet and unobtrusive, and she liked him for it. "It is enough," said she; "to stay that he is unlike Fanny is enough. It implies everything amiable. I love him already." "I think you will like him, "said Elinor, "When you know more of him." (Austin, 1990: 73)

This shows that a mother takes care of her daughters attentively, so if the daughters get some troubles, she can help them, and her daughters can feel the mother's love and affection to them.

Besides, the roles of mothers or wives are greater than those of the fathers or husbands in bringing up their children. It is because the women know better what they should do with them. Women surely understand whether a child will get a good education, live in a good neighborhood, or will meet the right people.

Austen (1990) reflects in the novel that having a good relationship between a mother and a daughter is quite crucial as shown in the following.

"Oh, mama, how shall we do without him?" 'My love, it will be scarcely a separation. We shall live within a few miles of each other and shall meet every day of our lives. You will gain a brother, a real, affectionate brother. I have 
Potrayal of the Nineteenth Century English Women in Jane Auste's Sense and Sensibility, Alamsyah, Azmir Pasaribu, Zulfan Sahri

the highest opinion in the world of Edward's heart. (Austin, 1990: 78)

This shows that a good relationship between a mother and a daughter brings supports very much to a harmonious relationship in the family. This is also one of the duties of a mother. Therefore a woman has a crucial role in the family and cannot be simply ignored since the running of a family depends much on a woman.

\section{Woman's Social Life}

The family is the smallest group in the society. It is also the basis of a civilized society. It consists of father, mother and children, if any. But, sometimes a family can also consist of the parents, the children and the grandparents who live with them.

At the basis of the society, the family cannot be free from social system. These social systems are social roles that are appropriate in a given situation. Social system is the notion of system, which is not peculiar to any form of knowledge but is a conceptual tool with a widespread currency in the natural and social sciences. Therefore, social systems are rules or standard individual behaviors which have the conformity without external rewards, punishments and common guidelines for social actions.

In the novel, the social life of women in the society of this period is not far different from their life in the family. They cannot do much as the men do in any aspect of life; they are under the control of men. This is because most people 
think that the women do not deserve to work of make business outside. Therefore, the women should depend their life on men.

Regarding this, women should be able to make a good approach to their husbands so they could live nicely and prosperously. This is like what Mrs. Dashwood does to her husband. She attempts hard to take the husband's heart for her, especially about her position at home and the properties that Mr. Henry Dashwood, her late father-in-law, leaves for her husband.

Undoubtedly and after all you have no thanks for it. They think themselves secure, you do no more, what is expected, it realizes no gratitude at all. If I were you, whatever I did should be done at my own discretion entirely. I would not bind myself to allow them any inconvenient some years to spare ... and you know dear, what about myself, no pieces from what you have got? I will always support you, and be with you in any time. I love you and my love is for you only and that will only be vanished in time of my eternal separation. (Austin, 1990: 80)

This shows that Mrs. Dashwood has to make some words of flattery to her husband at least to get some from what Mr. Dashwood has inherited. The wife does everything to get what she needs from her husband. Mrs. Dashwood's interference with her husband's way of thinking looks successful because John is distinctly ready to accept her ideas about the sharing of the property with his sisters although he should break his promise to his own self. And at the same, the wife also expects that she would get something from the property.

Man thinks too much of himself and his ideas because a common man is self-centered. That is why flatterers have always been a success in this world. 
Potrayal of the Nineteenth Century English Women in Jane Auste's Sense and Sensibility, Alamsyah, Azmir Pasaribu, Zulfan Sahri

There used to be flatterers in the courts and there are flatterers even in our dayto-day life. One can win the favor of others by praising the qualities which the other man possesses or toy pleasing the beauty, the lady has. If a person is able to play round the weaknesses of the other man, it is very easy for him to win his favor.

Mrs. Dashwood's conduct indicates the portrayal of women in the nineteenth century, on one side, living with the men to gain property and prosperity; on the other side, women look too weak to get involved in men's business since it is described that Mr. John Dashwoold may do what he wants to his sisters, and they cannot do anything to their brother's decision.

The fact that women cannot be or are not allowed managing any business and consent with the activities outside socially is apparently true. They grow up to live with the men since their dependence with the men is really high. They live to give birth to children and to serve their husbands as well as they could. This matter can be shown from the condition where the women, like Mrs. Dashwood, after the death of his husband, depends her life on his son, John.

Mrs. Dashwood has been informed that by her husband of the solemn promise on the part of his son in their favor, which gave comfort to his last earthly reflections and next to this, Mrs. Dashwood would be supported by her son, and all will managed by the son. (Austin, 1990: 89)

This shows that the life a woman is totally dependent on a man. Mrs. Dashwood has no rights at all to continue her husband's business. The whole inheritance goes to their son. Though the son does not leave the mother or does 
something bad to her, still she is powerless. The son is good for he is surely ready to take care of his mother and the mother looks a very weak figure.

\section{CONCLUSION}

There are three points of discussion found throughout the analysis; all of which deal with the picture of the nineteenth century English women.

The first deals with the rights of woman in obtaining property especially the one inherited from parents. The laws of the era forbid the women to gain the property as there is an article of the laws stating that married women are totally under the control of their husbands. This is unfair because the matters of inheritance are based on luck; if the husband is good, nothing will happen, but the problem is when a woman coincidently gets a bad husband then all will be ruined.

The second does with the roles of women in the family. A woman will never be able to become a decision maker in the family since the main duties of the women is to serve the husband, give births to children and take care of the children. Again this is unfair as such a system will create a tyranny in a family.

The third deals with the roles of women in society. A woman is surely forbidden to do any type of job or business. This shows that Mrs. Dashwood has to become a home woman, meaning that she will never be able to get in touch with the outside world.

The single most compelling reason to care about Sense and Sensibility is totally up from, so up front, in fact, that Jane Austen practically smacks us in the 
Potrayal of the Nineteenth Century English Women in Jane Auste's Sense and Sensibility, Alamsyah, Azmir Pasaribu, Zulfan Sahri

face with it. The whole book is basically an extended debate between two things most of us know well, logic and emotion, that is to say, sense and sensibility. The fact of the matter is, while it is also a novel about the nuances of nineteenth century social mores, family life, and economic reality, Austen's book primarily forces all of its readers to contemplate the positions of a woman in society.

\section{REFERENCES}

Austen, Jane. (1990). Sense and Sensibility. New York: Macmillan.

Bodgan, Michael \& Biklen, James. (1992). Qualitative Approach. New York: Blankmount.

Erickson, Judith. (1999). Property Rights of Women in Nineteenth-Century England. London: Oxford Press.

Fausto-Sterling, Anne. (2010). Sexing the Body: Gender Politics and the Construction of Sexuality. New York: Basic Books.

Perkin, Joanne. (2010). Women of the Victorian Era. New York: Stanley House.

Sarah, Wise. (2000). The Blackest Streets: The Life and Death of a Victorian Slum. London: Vintage Books.

Shanley, William. (2000). Women Marital Status. London: Housman. 